Pamiętnik Literacki 2015, 3, s. 250-257

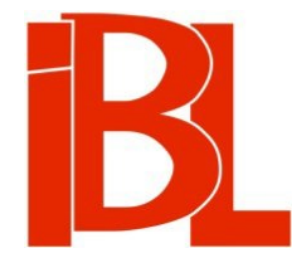

\title{
Pionierska monografia
}

Sławomir Buryła

Rec. : Grzegorz Niziołek, Polski teatr Zagłady.

(Warszawa 2013) 
SŁAWOMIR BURYŁA Uniwersytet Warmińsko-Mazurski, Olsztyn

\section{PIONIERSKA MONOGRAFIA}

Grzegorz Niziołek, POLSKI TEATR ZAGŁADY. (Recenzenci: Krystyna Duniec, Ewa Guderian-Czaplińska. Indeks: Dorota Buchwald, Monika Krawul). (Warszawa 2013). Instytut Teatralny im. Zbigniewa Raszewskiego / Wydawnictwo Krytyki Politycznej, ss. 588.

Olbrzymia objętościowo publikacja Grzegorza Niziołka udowadnia, jak wiele jest jeszcze do zrobienia w rodzimych badaniach nad Holocaustem. W przypadku Polskiego teatru Zagłady należy od razu dodać, iż synteza ta wypełnia poważną lukę w refleksji naukowej, to jedna z tych, na które czeka się latami. Książka Niziołka jest przy tym napisana z erudycyjnym i intelektualnym rozmachem. Jej autor nie tylko omawia ze znawstwem sceniczne realizacje tematyki Shoah, ale dokonuje tego w sposób intrygujący i inspirujący. Mamy więc pracę o charakterze podsumowujacym, o dużej wartości informacyjnej, mogącą służyć za kompendium, a równocześnie za interesującą propozycję analityczną i interpretacyjną.

Monografia Niziołka składa się $z$ dwóch niesymetrycznych części. Pierwszą z nich ( $Z a-$ głada i teatr) postaram się przedstawić holistycznie, rezygnując ze skrupulatnego omówienia konstytuujących ją szkiców: Teatr gapiów, Kto nie był w Auschwitz?, Odgrywanie Żyda, Źle zobaczone, Bez żałoby. Zawierają one pojęcia kluczowe dla rozprawy, nakreślają tło intelektualne, stawiaja pytania i zagadnienia szczegółowo rozpatrywane później przy każdej ze sztuk prezentowanych przez Niziołka.

Do najważniejszych wątpliwości sformułowanych we wstępie należy ta oto: „Zjawisko ślepoty teatru na Zagładę jest [...] niepokojące i paradoksalne. Wszelkie świadectwa Zagłady są wszak wypełnione metaforami teatralnymi, nie da się przecież Zagłady opowiedzieć bez takich słów jak: gra, maska, iluzja, reżyseria, rola, scena, kulisy, obscena, tragedia, ofiara. Ci, którzy przeżyli, gotowi są określać siebie jako "komediantów", którym tylko dzięki "grze" udało się przetrwać. [...] Co więcej, metafory te nie tylko pozwalają opisać zdarzenia Zagłady, ale je na swój sposób warunkują, organizują, wprawiają w ruch. Każde zdarzenie Zagłady opierało się na dystrybucji ról i organizowaniu pola widzialności. Teatr był zatem zaangażowany w dzieło Zagłady jako dostarczyciel zarówno złowrogich strategii wytwarzania iluzji, usprawiedliwiania postaw pasywności, jak i narzędzi ocalenia (chociażby dzięki zmianie tożsamości ukrywających się osób)” (s. 32). W pierwszej części Polskiego teatru Zagłady Niziołek udziela na pytania o „ślepotę polskiego teatru na Zagładę” kilku odpowiedzi (bo przecież nie ma jednej). Nie bez znaczenia sa przywoływane wielokrotnie przez znawców tematu uwarunkowania społeczne i historyczne, związane $z$ polityką komunistów wobec wciąż żywych wydarzeń z przeszłości. Badacz, tropiąc inne przyczyny, na eksponowanym miejscu stawia pasywność świadka, jego bierna pozycję sprowadzająca się do oglądania cudzego cierpienia z bezpiecznej perspektywy. Słusznie więc powiada Niziołek: „W odniesieniu do polskiego teatru powojennego należałoby mówić nie tyle o granicach reprezentacji, ile o granicach odczytywalności zawartego $\mathrm{w}$ przedstawieniach świadectwa - o doświadczeniu niepamięci uruchamiającym pracę powtórzenia” (s. 87). To fundamentalne spostrzeżenie. Problem, przed jakim staje polski teatr i polski widz, dotyczy komunikowalności relacji polsko-żydowskich, do których rodzimi twórcy powracaja po latach, wiedzeni potrzebą opisania na nowo historii, które wcześniej uzyskały już odpowiednią formę w świadomości powszechnej.

Teatr lat 1945-1989 zarówno wspierał tendencje cementujące „narodowe upiory”, jak i - częściej - burzył je, naruszając dobre samopoczucie odbiorcy. Nie zawsze udawało się mu pokonać ścianę (prze)milczenia. Dotarcie do polskiego widza nie było łatwe. Sztuka mocno osadzona w realiach historycznych mogła się narazić na zarzut, iż opowiada o czymś, co w tym kraju wszyscy dobrze znają, strategie metonimiczne $z$ kolei musiały się liczyć z ewentualnością niezrozumienia, powierzchownego odbioru. Nie tylko „niedostatek empatii” (s. 58) 
odpowiadał za to, że w rodzimym teatrze nie powstała sztuka pobudzająca do dyskusji, taka jak choćby Namiestnik Rolfa Hochhutha. Wydaje się, iż recepta była prosta - odważna fabuła wyraźnie odsyłająca do Holocaustu, będąca aktem jawnej niezgody wobec tego, co stanowiło podstawę „zmowy milczenia” między władzą a społeczeństwem. Należało więc zdecydowanie uderzyć w warunki kontraktu, który nieformalnie podpisali komunistyczni dygnitarze z obywatelami PRL. Gwarantował on ochronę „dobrego imienia”. Reakcja na Shoah Claude’a Lanzmanna pokazuje zgodność partii i społeczeństwa w ocenie postaw „polskich sąsiadów” w czasie Zagłady. Dowodzi również, że powstanie takiej sztuki o Holocauście, która wywołałaby dyskusję i emocje, było możliwe. Kłopot tkwił zatem nie tylko w odbiorcy i jego nastawieniu, ale po części też w twórcach i sposobach prezentowania relacji polsko-żydowskich. Artyści jednak musieli mieć świadomość przynajmniej dwóch zagrożeń. Pierwszym była obawa, że ukazanie expresis verbis ciemnych kart polskiej historii może wywołać blokadę w odbiorcy, a nie zachęcać do rozmowy. Drugie zagrożenie to dystans i nieufność widza wzmacniane przez ośrodek władzy, mogący się odwołać do mediów i reżimowych dziennikarzy. Nie wolno zapominać o roli instytucji w budynku na Mysiej. Kamila Budrowska w Zatrzymanych przez cenzurę wydobywa na światło dzienne dwa dramaty nie dopuszczone do druku przez GUKPPiW: Dni grozy Rajmunda Hempla oraz Lamus Nadziei Druckiej $^{1}$. Teoretycznie sztuki „nieprawomyślne” miały największe szanse ukazać się między 1945 a 1949 rokiem, kiedy cenzura nie działała jeszcze sprawnie. Wówczas jednak było za wcześnie - z psychologicznego punktu widzenia - na rozliczenia z trudna przeszłością. Wtedy też „impuls wyparcia płynął z próby odbudowania tradycyjnych wzorców polskiej kultury, szczególnie tych ukształtowanych na bazie mitów romantycznych [...]" (s. 62).

Od przełomu z 1989 roku żyjemy w czasach, w których coraz donioślejsze staje się inne wyzwanie: jak w dobie nowych mediów, kultury popularnej i Internetu mówić o Auschwitz ${ }^{2}$. A w konsekwencji - jaka powinna być rola teatru, jaki kształt przekazu artystycznego, aby nie stracić kontaktu ze współczesnym odbiorcą.

Część drugą, Teatr i Zagłada, otwiera szkic Wojna żydowska, haniebna, będący analizą Wielkanocy Stefana Otwinowskiego. Niziołek słusznie zwraca uwagę na instrumentalne wykorzystanie przez autora romantycznych mitów wspólnej walki i cierpienia. Odwołanie się do tego, co łączy (martyrologii), jak do XIX-wiecznej tradycji niepodległościowej (którą ma urzeczywistniać powstanie w getcie i jego młodzi żołnierze, zapatrzeni w dzieje polskich zrywów w obronie godności i niezależności narodowej), winno wywołać empatię u widza. Tym tropem poszedł Leon Schiller, gdy jesienią 1946 wystawił Wielkanoc w Teatrze Wojska Polskiego. Ów apel do „dobroci serca”, jak stwierdza Niziołek po zapoznaniu się z zachowaną dokumentacją na temat spektaklu Schillera, nie powiódł się. Dlaczego? Wcześniej rozbiciu musiał ulec język, w którym Polacy myśleli o wciąż żywej przeszłości, stanowiący tarczę ochronną społeczeństwa. Na takie myślenie składało się szereg przekonań - wśród nich wyobrażenie o byciu ofiara, jako jedynej roli, w której mogli być obsadzeni obywatele II Rzeczpospolitej w czasach hitlerowskiej okupacji.

Socrealizm - z niechęcią przyglądający się pewnego typu tematom wojennym, również Zagładzie - w niektórych obszarach budował płaszczyzny porozumienia $\mathrm{z}$ narodem. Jedna Z nich był, wspomniany już, problem ochrony „dobrego imienia” obywateli konfrontowanych z okrucieństwami wojny. Dotyczyło to także relacji polsko-żydowskich, w znacznej części objętych tajemnicą, te zaś, które dopuszczano do głosu, stawały się przedmiotem manipulacji politycznych. Niziołek omawia owe zagadnienia w artykule Zbędny Żyd i karzacy piorun, sięgając po dramat Jerzego Lutowskiego Próba sit, wystawiony przez Aleksandra

$1 \quad$ K. B u d row s k a, Zatrzymane przez cenzurę. Inedita z połowy XX wieku. Warszawa 2013.

2 Zob. jedyną na ten temat, niewolną wszakże od błędów, publikację M. Kaźmi e r c zaka Auschwitz $w$ Internecie. Przedstawienia Holokaustu w kulturze popularnej (Poznań 2012). 
Bardiniego w Teatrze Polskim w Warszawie w 1951 roku. Niezwykle ciekawe są spostrzeżenia badacza wydobywające $z$ Próby sił te partie, które przełamują sztancę ideologiczną. W sztuce Lutowskiego bowiem nie następuje „wyleczenie z przeszłości”, jak tego oczekiwali stalinowscy dygnitarze.

W szkicu Lepsze od Saganki Niziołek przybliża - cieszący się dużą popularnością w Teatrze Dramatycznym - grany w sezonie 1957/58 Pamiętnik Anny Frank. Zainteresowanie zapiskami żydowskiej dziewczynki zdawało się dorównywać słynnej powieści Françoise Sagan Witaj, smutku. Niziołka zajmuje przede wszystkim polska recepcja Pamiętnika Anny Frank. Stawia on tezę o bezpośredniej zależności między antysemickimi zajściami w roku 1956 a decyzją o adaptacji teatralnej tekstu Frank. Byłaby to odpowiedź na dochodzące do głosu w roku 1956 antyżydowskie wystąpienia w szeregach partii oraz na zachowania (niewielkiej) części obywateli PRL ${ }^{3}$.

Omawiając obraz Holocaustu w teatrze polskim lat sześćdziesiątych Niziołek koncentruje się na trzech tekstach: Pasażerce Zofii Posmysz, jej filmowej wersji wyreżyserowanej przez Andrzeja Munka ${ }^{4}$, Dochodzeniu Petera Weissa, wystawionym przez Erwina Axera, oraz Pustym polu Tadeusza Hołuja w reżyserii Józefa Szajny. Traktuje o tym szkic Scena pierwotna.

Pasażerkę czyta Niziołek przez pryzmat Freudowskiej „sceny pierwotnej”. Jak stwierdza, dla polskiej świadomości zbiorowej taką „scenę pierwotną" stanowił (stanowi) Auschwitz-Birkenau. To m.in. w oparciu o okupacyjną historię obozu oświęcimskiego Polacy budowali swoją powojenną tożsamość. Spór o ekspozycję muzealną w Auschwitz był więc sporem o kształt narodowej pamięci i narodowej przeszłości.

Puste pole Hołuja to utwór przeciętny, który w inscenizacji Szajny zyskał bardzo dużo. Znakomity artysta de facto powołał do życia nowe dzieło, będace sugestywną mieszanina przerażenia, grozy, zmysłowości i komizmu. Skutkowało to atmosfera groteskowości i scen tragikomicznych. Wprowadzone przez Hołuja dwie perspektywy czasowe (teraźniejsza i przeszła) uległy u Szajny jeszcze większemu rozmyciu, podobnie jak warstwa fabularna.

Alvin H. Rosenfeld w Podwójnej śmierci przeprowadza krytykę Dochodzenia, zarzucając mu, iż antykapitalistyczna retoryka tego dramatu nie pozwala uchwycić właściwego sensu Auschwitz ${ }^{5}$. Zarówno Puste pole Szajny, jak i Dochodzenie w reżyserii Axera dobrze wpisywały się w epoke gomułkowską. Pomijała ona dzieje Birkenau i dokonanej tam masowej zbrodni na Żydach. Peerelowskie władze w imię uniwersalizmu zacierały żydowskie cierpienie. Niewątpliwie Puste pole zawiera przynajmniej jeden motyw godny uwagi i odbiegający od zaleceń komunistycznych dygnitarzy. Chodzi o znany problem „żydowskiego złota”. U Hołuja beneficjentami żydowskich kosztowności są dawni więźniowie obozu. To dość odważne rozwiązanie i odmienne od oczekiwań propagandy, ale i społeczeństwa.

W Oklaskach $i$ śmiechu $w$ Narodowym Niziołek przywołuje zapomniana inscenizację Namiestnika Hochhutha. W dorobku artystycznym Kazimierza Dejmka przytłoczyły ją zrealizowane niecałe dwa lata później Dziady. Wystawienie Namiestnika było zabiegiem ryzykownym. W połowie lat sześćdziesiątych trwała bowiem konfrontacja komunistycznego reżimu z Kościołem, której istotnymi elementami były obchody milenijne oraz list biskupów polskich do biskupów niemieckich. Zachodziła obawa, że ekipa Gomułki wykorzysta antypapieską sztukę Hochhutha w walce $z$ Kościołem.

3 Zob. P. M a c h cewicz, Polski rok 1956. Warszawa 1993.

$4 \quad$ Wskazując na teatralne konotacje Pasażerki i kwalifikując ją jako dzieło przynależne do historii teatru Ni zi ołe k pisze: „Munk nie zawahał się zamienić przestrzeni dawnego obozu w gigantyczną instalację, wypełnić jej na nowo ruchem, zaludnić, uczynić terenem rzeczowych rekonstrukcji. Dlatego film czasami może się wydawać dokumentalnym zapisem artystycznego performansu, rozegranego przez Munka z rozmachem na terenie byłego obozu Auschwitz-Birkenau” (s. 243).

5 A. H. Ro s e n feld, Podwójna śmierć. Rozważania o literaturze Holocaustu. Przeł. B. Kr a w c owi c z. Warszawa 2003, s. 210-215. 
W Archiwum brakującego obrazu Niziołek raz jeszcze każe nam spojrzeć na książkę legendarną, obrosłą bogatą literatura przedmiotu - Rozmowy z katem. Dla badacza zarówno tekst Kazimierza Moczarskiego, jak jego wersja teatralna, reżyserowana przez Andrzeja Wajdę, są przyczynkiem do rozważań nad taką konstrukcją obrazu relacji polsko-żydowskich, by stał się on płaszczyzną porozumienia artysty ze społeczeństwem. Niziołek tym samym podejmuje trop wskazany niedawno przez Bartłomieja Krupę, pytającego o powody braku wątku Zagłady w recepcji Rozmów z katem ${ }^{6}$. Aby w pełni pojąć sens paktu zawartego ze społeczeństwem w spektaklu Wajdy, nie wolno zapominać o kilku zmiennych. Niziołek przekonująco je prezentuje. Po pierwsze, od połowy lat sześćdziesiątych twórca Kanału wkracza w nową fazę aktywności artystycznej: rozprawienie się $\mathrm{z}$ narodowymi mitami zastępuje tematami, które mogą mieć większy oddźwięk społeczny i pozwolą nawiązać porozumienie $z$ odbiorcą. Po drugie, szukając spotkania $z$ widzem, Wajda rozlicza się $z$ własną biografią. Zarówno postać Moczarskiego, jak wyeksponowane (nie mające wiele wspólnego $\mathrm{z}$ faktami historycznymi) zaangażowanie podziemia w powstanie $\mathrm{w}$ getcie oraz powojenne prześladowania, dotykające środowisk akowskich miały gwarantować pozytywny odzew odbiorcy. Był to też szerszy problem, w którym kryło się pytanie, jak powrócić do zagadnień żydowskich po Marcu '68, jak odzyskać język komunikacji społecznej zdominowany przez antysemicką i narodową retorykę spod znaku Mieczysława Moczara. Rozmowy z katem (i utwór Moczarskiego, i - chyba w jeszcze większym stopniu - przedstawienie Wajdy) były wyrazem „paktu o nieagresji”. Tym łatwiejszym do sygnowania, że część środowisk opozycyjnych również nie miała ochoty na roztrząsanie „tematów żydowskich”, zwłaszcza że rozmowy o nich często przybierały drażliwą postać.

Nie tylko $\mathrm{z}$ racji miejsca, jakie im poświęcono, ale także $\mathrm{z}$ powodu wagi dla zilustrowania kluczowych w koncepcji Niziołka mechanizmów pamięci i zapominania, odsłaniania i niezasłaniania oraz wypierania i powtórzenia realizacje artystyczne Tadeusza Kantora i Jerzego Grotowskiego stanowią właściwe centrum Teatru i Zagłady.

O spektaklach Kantora traktują dwa szkice: Publiczność zgnieciona oraz Lęk i co dalej... Niziołek śledzi u Kantora przebłyski tego, co niewyrażalne, nietematyzowalne - traumy. Wykorzystując koncepcję Doriego Lauba „zdarzenia bez świadka”7 akcentuje wyjątkowa pozycje odbiorcy Kantorowskich happeningów (np. Tratwa „Meduzy”) oraz sztuk scenicznych (m.in. Kurka wodna, Umarła klasa, Gdzie sa niegdysiejsze śniegi, Nigdy tu już nie powrócę). Jest on tym, który p a tr zy, towarzyszy artyście i jego dziełu, ale nie potrafi zrozumieć albo - inaczej - odszyfrować ukrytych sensów. Nie jest w stanie więc swego świadectwa komunikować. W tym porządku może przypominać milczenie lagrowego muzułmana. Strategia Kantora polega na wywołaniu wstrząsu u odbiorcy. Twórca Umarłej klasy chce wciagnaćc widza w niewygodną dla niego sytuację współuczestniczenia w cudzym poniżeniu, cierpieniu. Ale na obserwacji jego rola się nie kończy. Kantor zamierza go zaangażować do odnajdywania, tak w fabule, jak i w formalnej konstrukcji przedstawienia, śladów Katastrofy. Nie jest to zadanie łatwe. Autor Wielopola... Wielopola... - w zgodzie z własnymi deklaracjami - odżegnuje się od interpretacji uwydatniających w jego spektaklach odniesienia polityczne i historyczne. Zagłada pojawia się w pojedynczych, niewyraźnych odsłonach. Nabierając labilnych kształtów, nie daje się przyszpilić, często umyka uwadze recenzenta i publiczności.

Więcej miejsca poświęca Niziołek przedstawieniom Grotowskiego (szkice Teatr poza zasada przyjemności, Co jest $w$ Polsce nie do pomyślenia, Demontaż widzenia, a także w znacznym stopniu Efekt kiczu). Nie sposób nie odnotować licznych koincydencji między

6 B. Kru pa, O nieobecności Zagłady, czyli czytanie „Rozmów z katem” Kazimierza Moczarskiego. „Zagłada Żydów” 2011, nr 7.

7 D. La u b, Zdarzenie bez świadka. Prawda, świadectwo oraz ocalenie. Przeł. T. Ły s a k. „Teksty Drugie" 2007, nr 5. 
tymi dwoma twórcami. Ma też tego świadomość Niziołek. I Kantor, i Grotowski podejmują grę z publicznością. Jej przedmiotem jest kategoria niepamięci. W Umarłej klasie i w Akropolis nawiązania do eksterminacji Żydów są wyraźne, ale zarazem wyzbyte jednoznacznego kontekstu historycznego. Obydwaj artyści, by ocalić afektywną moc swych przedstawień, świadomie sytuują się na granicy między dosłownością a suspensem.

Od Akropolis Grotowski wplata w swe spektakle dwie figury Zagłady: muzułmana i obozu koncentracyjnego. Czyniąc to, prowadzi niebezpieczną, podwójną grę - „porusza się w sferze podwojonego tabu: historycznego i seksualnego" (s. 304). Sposób ujęcia ludzkiej cielesności mógł wywołać oburzenie, podobnie jak ujęcie Auschwitz. Nie wywołał, bo nie został zrozumiany przez widzów. Tymczasem w ciekawym odczytaniu Niziołka nawiązania do dramatu Wyspiańskiego służą w Akropolis negacji mitów europejskiej tradycji. Akropolis w interpretacji Grotowskiego wprowadza do przedstawienia horyzont Auschwitz. Wedle Niziołka Oświęcim jest u Grotowskiego nowym, prześmiewczym, mitem założycielskim cywilizacji po Shoah.

Jeśli w Akropolis Grotowski starał się prowokować, to w mało znanym Studium o Hamlecie „mamy [...] do czynienia z próbą radykalnego gestu samowykluczenia ze zbiorowości, z gotowością narażenia się wszystkim, $\mathrm{z}$ pragnieniem przekroczenia wszelkich spajających wspólnotę porządków symbolicznych - a więc $z$ formą społecznego samounicestwienia" (s. 313). W roli Hamleta artysta obsadził Żyda: prześladowanego, napiętnowanego przez otoczenie - prymitywnych polskich chłopów. Grotowski odtwarza w Studium o Hamlecie stereotypowe wyobrażenie Żydów jako tchórzy, biernie znoszących spadające na nich ciosy. To stereotyp głęboko zakotwiczony w kulturze ludowej i nie tylko. Spektakl odwołuje się przy tym świadomie do fantazmatycznego obrazu prymitywnego chłopstwa. Ale i tu „wątek żydowski” został niemal zupełnie pominięty w recenzjach. Próba zniszczenia narodowego narcyzmu nie powiodła się. W Księciu Niezłomnym Grotowski zmienia taktykę: w wizji cierpiącego Chrystusa proponuje sojusz z widzem. Sojusz, który nie unieważni pozycji muzułmana i Żyda wydanego na bestialstwo i sadyzm innych. Ksiażę Niezłomny obnaża jednak cenę owego porozumienia: wyparcie wszystkiego, co neguje niewinność świadka.

Zamknięcie bloku tekstów o Grotowskim stanowi Efekt kiczu. Niziołka interesuje kicz nie jako immanentna kategoria dzieła sztuki, ale jako rezultat jego recepcji. $Z$ przedstawień Grotowskiego (Ksiażę Niezłomny) czy Swinarskiego (Dziady) polski widz z radością i bezrefleksyjnie wydobywał te wszystkie fakty, które oferowały nadzieję rozgrzeszenia albo konstruowały iluzję przemieniania „złej historii”. W Księciu Niezłomnym i w Dziadach Swinarskiego rewitalizowane są mity konsolidujące naród, ujawniające pokłady heroicznej energii tkwiące w rodzimej przeszłości - opowieści, pozwalającej na duchowe oczyszczenie, odrodzenie i uwznioślenie tragicznych wydarzeń z historii. Niziołek - powołując się na Rolanda Barthes'a - przypomina, że „Mit nie niesie żadnej prawdy o historii, natomiast zawsze stara się dostarczyć jej alibi” (s. 430). Wydaje się, iż znaczna część widzów w Księciu Niezłomnymi w Dziadach Swinarskiego poszukiwała alibi, a nie wiedzy o żydowskim cierpieniu. Takie też były nastroje i reakcje większości społeczeństwa. Kicz łączyłby się więc z potrzebą łatwego pocieszenia, gwarantowanego przez zatrzymywanie się na powierzchni zjawisk, ignorowania głębi na rzecz prostych prawd, powszechnie przyjętych klisz i uproszczeń.

W teatrze lat osiemdziesiątych - w czasie pomiędzy stanem wojennym a nadchodzaca wraz z rządami Gorbaczowa epoką zmian - odnotowuje Niziołek spektakl Jerzego Grzegorzewskiego Pułapka, oparty na dramacie Tadeusza Różewicza. Jej bohaterem jest Franz Kafka. Zagłada pojawia się w Pułapce - w zgodzie $\mathrm{z}$ duchem niektórych interpretacji dzieł Kafki - jako fakt w porządku wyobrażeniowym, widmo uzasadniane nie w obszarze historycznych zdarzeń w tekście Różewicza, lecz w sferze przeczuć. W Punkcie bez dalszego ciagu Niziołek analizując Pułapkę przywołuje inną sztukę, Powolne ciemnienie malowideł (adaptacja słynnej powieści Malcolma Lowry’ego Pod wulkanem), i udowadnia, że u Grzegorzewskiego niemożliwe jest przeprowadzenie żałoby. To akt spóźniony, ale przede wszystkim niewykonalny $z$ racji totalnej destrukcji języka. Zamiast żałoby pozostaje melancholia i przeczucie 
katastrofy. Gdyby pominać widoczny u Grzegorzewskiego rozpad języka komunikacji, wolno byłoby przywołać nastrój powieści Piotra Szewca: Zagłady, Zmierzchów i poranków oraz Bocianów nad powiatem. Melancholijne spojrzenie na żydowski świat zniszczony przez Shoah ma zreszta wiele realizacji we współczesnej prozie (np. Weiser Dawidek Pawła Huelle, a wcześniej Włodzimierza Paźniewskiego Krótkie dni).

W zakończeniu Punktu bez dalszego ciagu Niziołek powraca do dręczącego go pytania, czy możliwe jest u Grzegorzewskiego przejście od melancholii do żałoby. Nie usłyszymy wszakże klarownej i jednoznacznej konstatacji. Nie pierwszy raz badacz pozostawia czytelnika $z$ wattpliwościami, jakby przymuszając do samodzielnej pracy myśli.

We współczesnym polskim teatrze znalazła odbicie również narodowa dyskusja o zbrodni w Jedwabnem. Presja tej dyskusji była tak silna, że niektóre spektakle - choćby aluzje do mordu w Jedwabnem były niewielkie, watpliwe - bezwiednie kojarzono z tymi wydarzeniami. Tak stało się $z$ Wymazywaniem Thomasa Bernharda reżyserowanym przez Krystiana Lupę. Traktuje o tym szkic HamletPsychoza. Niziołek pokazuje niezwykle finezyjnie zależności między Jedwabnem a problematyką Wymazywania. Nie są to jednak pokrewieństwa na zasadzie więzi między sztuką a rzeczywistością, lecz subtelne mechanizmy łączące się m.in. z naturą wyparcia i powtórzenia.

„Sprawą Jedwabnego” mocno naznaczona została twórczość Krzysztofa Warlikowskiego (czemu artysta dawał wyraz w swoich wypowiedziach na ten temat). W Antygonie Niziołek zastanawia się nad zasadnością wykorzystania greckiego mitu w Dybuku Warlikowskiego, ale też - szerzej - przykładania go do sytuacji polskiego społeczeństwa konfrontowanego z doświadczeniem Shoah. Można na lata 1945-2001 spojrzeć jako na „wielki i jednolity obszar niepamięci i zaniechania stosownych rytuałów żałoby” (s. 502). Sięgając po odczytanie toposu Antygony zaproponowane przez Jacques'a Lacana i Judith Butler, Niziołek pokazuje, jak Dybuk podważa dobrze zadomowione wizje tragicznego konfliktu w dramacie Sofoklesa. Jedna usprawiedliwia czyn Antygony, druga skupia się na dostrzeżeniu racji Kreona. Warlikowski konstruuje w bluźnierczy sposób opowieść o Antygonie (jest ona tą, która pożąda śmierci i autodestrukcji, nie zaś kapłanką żałoby). Nade wszystko odrzuca kategorię tragizmu pojętego tradycyjnie jako konflikt stron stwarzający jednak szansę na oczyszczenie. W Dybuku nie ma katharsis. Jest za to niezgoda na łatwe, wyuczone gesty i sentymentalne deklaracje.

Książkę Niziołka zamyka Widz obłudny, widz bezradny - rozważania o Naszej klasie Tadeusza Słobodzianka oraz (A)pollonii Warlikowskiego. Niziołek proponuje krytyczną lekturę Naszej klasy jako przekazu, który tyleż odkrywa, co skrywa niewygodne pytania zrodzone w dyskusji o Jedwabnem. Badacz przywołuje przy tym zastrzeżenia podnoszone przez Adorna: do jakiego stopnia wolno się posunać w oświecaniu słuchacza, by nie spowodować rezultatu odmiennego, niż zamierzamy, by nie wzbudzić oporu i sprzeciwu zamiast zrozumienia i żalu za popełnione winy? To wątpliwość towarzysząca wielu stronicom Polskiego teatru Zagłady. W interpretacji Niziołka Nasza klasa, wychodząc z założenia, że zło jest sceniczne, „przedstawialne” w swej bezpośredniości, brutalności (co wydaje się dalekie od wizji Kantora, Grotowskiego czy Grzegorzewskiego, odwołujacych się do metonimii ${ }^{8}$, a nie do konkretu), wikła je w system symbolicznych odniesień, nade wszystko zaś neutralizuje bilansowanie „dobrych” i „złych” uczynków. Pojawia się możliwość katartycznego oczyszczenia, którą daje świadomość rozliczenia grzechów przeszłości. Nasza klasa jest wciąż naszą klasą, choć zranioną w różnym stopniu, ale uczestniczką tej samej, okrutnej historii Polski ${ }^{9}$.

8 Kategorię metonimii jako kluczową dla najnowszej prozy polskiej omawia M. C u b e r (Metonimie Zagłady. O polskiej prozie lat 1987-2012. Katowice 2013).

9 „Klasę szkolną” będącą miejscem spotkania polsko-żydowskiego ciekawie analizuje E. Prok o p - J a n i e w szkicu Klasa szkolna jako polsko-żydowska strefa kontaktu (w: Pogranicze polsko-żydowskie. Topografie i teksty. Kraków 2013). 
Polemizując ze Słobodziankiem formułuje Niziołek doniosły sąd: „Straszna [...] jest nie tylko "polska wina", ale także jej "epizodyczność" i "zbędność" w monstrualnym dziele Zagłady, a także dręczący fakt aż tak zawężonego pola społecznej empatii wobec cierpienia, którego świadkami było polskie społeczeństwo. I jeśli w latach 40. trzeba było brać pod uwagę przede wszystkim obojętność polskiego społeczeństwa wobec dokonanej masowej zbrodni na Żydach, tak współcześnie należy zakładać powszechną ignorancję, brak dostatecznej wiedzy historycznej, przede wszystkim wiedzy opartej na empatii, wiedzy przeżytej, afektywnie przyswojonej. $Z$ tego powodu hipoteza "wyparcia" jest psychoanalitycznie nieskuteczna, martwa, słusznie więc odbierana przez znaczną część społeczeństwa jako coś mu narzuconego, z czym trudno się identyfikować. Nie postawiono, moim zdaniem, dość głośno pytania, czy wpisanie mordu w Jedwabnem w historię polskiego antysemityzmu nie tłumaczyło zbyt jednostronnie i zbyt racjonalnie kwestii polskiego współudziału w Zagładzie. Sprowadzało zbrodnię w Jedwabnem do jeszcze jednego pogromu (i po raz kolejny ograniczało pole widzenia), a horror tego pogromu doskonale spełnił funkcje kulminacji w konstruowanym dramacie o polskim antysemityzmie" (s. 551). Ten długi cytat każe postawić zagadnienia przekraczające ramy niniejszej recenzji. Zasygnalizujmy jedno $z$ nich: polska literatura (nie tylko teatr) „po Jedwabnem” nie może czuć się zwolniona z diagnozowania różnych wymiarów naszego uczestnictwa w eksterminacji Żydów.

Inną strategię, w ocenie Niziołka, obiera (A)pollonia. Warlikowski zdecydowanie oponuje przeciwko tym, którzy w publicznej debacie o Jedwabnem chcieliby widzieć „przepracowanie" trudnych stosunków polsko-żydowskich, obnażenie i przyznanie się do winy, a w rezultacie powód do zamknięcia rozmowy o ciemnych kartach naszej przeszłości. (A)pollonia jest jak najdalsza od pocieszenia, optymizmu. Celem Warlikowskiego staje się uczynienie sceny „miejscem uprawiania odpowiedzialności za zdarzenia od nas niezależne” (s. 562). To projekt sztuki, która ma jątrzyć, moralnie oceniać rzeczywistość, wykazywać swoją niezgodę i negować dobre (jeszcze w zalążku) samopoczucie widza.

Prezentując fundamentalną książkę Niziołka wypada przybliżyć pominięty przez nas aspekt metodologiczny. Subtelne, misteryjne analizy w Polskim teatrze Zagłady wznoszą się na fundamentach poststrukturalistycznych i psychoanalitycznych. Te ostatnie odgrywają główną rolę w analizach Niziołka. Kategorie żałoby, wyparcia, melancholii, przepracowania, utraty, rany, traumy pochodzą ze słownika psychoanalitycznego. Obok prac Sigmunda Freuda, które są tu często chronologicznym i myślowym punktem wyjścia, pojawiają się dzieła Melanie Klein, Carla Gustava Junga, jak też rozprawy klasyków badań postpamięci, traumy (Marianne Hirsch, Shoshana Felman, Dominick LaCapra). Jednak wybór psychoanalizy jako narzędzia mówienia o miejscu Shoah w rodzimej kulturze i świadomości nie jest przypadkowy. Nie wynika także z mody, lecz ze względów kompozycyjnych i merytorycznych. Osią refleksji Niziołka są bowiem pojęcia niewidzialności, nieobecności Zagłady. Sztuka pełni rolę medium stale przypominającego o Holocauście, nie pozwalającego zapomnieć nie tylko o zbrodni na masową skalę, o związanym $\mathrm{z}$ nią ludzkim cierpieniu i bólu, ale i o postawach „sąsiadów”. Praca krakowskiego badacza ma podwójny wymiar. Tropieniu śladów Wydarzenia ${ }^{10} \mathrm{~W}$ przekazach teatralnych towarzyszy namysł nad mechanizmami pamięci zbiorowej zasadami jej przyswajania i neutralizowania, modyfikowania i instrumentalizacji.

Analizując przekazy tużpowojenne Niziołek słusznie podejrzewa, iż „w polskiej kulturze [...] istnieje olbrzymi zbiór tekstów [...] w większości słabo znanych użytkownikom tego [tj. polskiegol języka, niechętnie przyjmowanych, marginalizowanych bądź całkowicie usuwanych z obszaru kulturowej pamięci i świadomości” (s. 158). Pomińmy teraz przyczyny tego fenomenu, owego ostracyzmu kulturowego (o nich w dużym stopniu traktuje rozprawa Niziołka),

10 Kategorie „Wydarzenie” zapożyczam od K. B oj a r s ki ej (Wydarzenia po Wydarzeniu. Białoszewski-Richter-Spiegelman. Warszawa 2012). 
a raz jeszcze podkreślmy ogrom epickich, poetyckich i autobiograficznych świadectw Shoah utrwalonych w polszczyźnie. Skalę zjawiska najpełniej oddaje Literatura polska wobec Zagłady (1939-1968) ${ }^{11}$. Polski teatr Zagłady znakomicie uzupełnia przywołaną monografię o przekaz sceniczny.

Abstract

SŁAWOMIR BURYŁA University of Varmia and Masuria, Olsztyn

\section{A PIONEERING MONOGRAPH}

The review considers Grzegorz Niziołek's monograph Polski teatr Zagłady (The Polish Theatre of Extermination). The pioneering study treats of the Holocaust threads in Polish post-war theatre. The author does not limit his considerations to finding the Holocaust motifs, but also shows the modes in which they were silenced and hidden.

11 Literatura polska wobec Zagłady (1939-1968). Red. S. Buryła, D. Krawczyńska, J. Leo cia k. Warszawa 2012. 